\title{
Screening of anticholinesterase activity of alkaloids from extracts of ten selected indigenous plants in Mindanao
}

\author{
Ferlien Mae Brieta ${ }^{1}$, John Bryan Ruba ${ }^{2}$, Sema Esnaira ${ }^{3}$, Silkay Pabio ${ }^{4}$, Vivien Leigh Mina ${ }^{5}$ \\ $1,2,3,4,5$ University of the Immaculate Conception, Davao City, Philippines
}

\author{
Keywords \\ Anticholinesterase activity \\ Alkaloids \\ Alzheimers' disease \\ Toxicity test \\ FTIR
}

Received: 23 April 2018

Accepted: 25 May 2018

Published: 5 June 2018

\begin{abstract}
This study was done with the intent to screen the acetylcholinesterase activity of alkaloids from plant extracts often selected indigenous plants in Mindanao. Determination of the functional groups which may attribute to the anticholinesterase activity was done using the Fourier Transform Infrared Spectroscopy (FTIR). The presence of nitrogen, carbonyl group, hydroxyl groups, and aromatic rings was found in Costus speciosus, Euphorbia hirta, Ipomoea aquatica and Mimosa pudica. The results of the acute oral toxicity test show that at $2000 \mathrm{mg} / \mathrm{kg}$, Costus speciosus, Euphorbia hirta, Ipomoea aquatica and Mimosa pudica extracts are classified as Category 5: practically non-toxic based on the Globally Harmonised System [1]. Another purpose of this study is to acquire the Approximate Inhibitory Concentration $\left(\mathrm{AIC}_{50}\right)$ of the extracts using the Ellman method to determine the \% inhibition at concentrations logarithmically determined, and linear regression was used to calculate the $\mathrm{AIC}_{50}$. The $\mathrm{AIC}_{50}$ of C. speciosus, E. hirta, I. aquatica and M.pudica extracts are $4.18 \mathrm{mg} / \mathrm{mL}, 3.74 \mathrm{mg} / \mathrm{mL}, 3.68 \mathrm{mg} / \mathrm{mL}, 4.18 \mathrm{mg} / \mathrm{mL}$, respectively and their corresponding $\mathrm{AIC}_{50}$ range are $3.13-5.23 \mathrm{mg} / \mathrm{mL}, 2.81-4.68 \mathrm{mg} / \mathrm{mL}, 2.76-4.60 \mathrm{mg} / \mathrm{mL}$ and $3.13-5.23 \mathrm{mg} / \mathrm{mL}$. Furthermore, the AIC50 of the plant extracts was compared statistically with the positive control (Donepezil) to know if there is a significant difference. Results show that the significant value 0.287 is greater than $\alpha=.05$ (2-tailed). The researchers failed to reject the null hypotheses that there is no significant $\mathrm{AIC}_{50}$ difference between of C. speciosus, E. hirta, I. aquatica and M. pudica extracts and the positive control, Donepezil. Hence, the anticholinesterase activity of the plant extracts are comparable with the anticholinesterase activity of positive control, Donepezil.
\end{abstract}

(C) 2018 The Author(s). Published by TAF Publishing.

\section{INTRODUCTION}

Alzheimer's disease is a complex multifactorial neurogenerative disease and is most common among elderly populations [2]. Based on a study conducted by Alzheimer's Disease International, in South East Asia alone, there is an estimated 51.2 million elderly people, $5 \%$ of which are suspected of having dementia. This is expected to double over the next 20 years. It also has been predicted that this disease will affect 1 in 85 people globally by 2050 . The pathological features identified are are amyloid plaques, neurofibrillary tangles, inflammatory processes and disturbance of neurotransmitters mainly Acetylcholine [3, 4, 5], progressive loss of neurons, which is the major source of cholinergic innervations that leads to progressive and irreversible impairment of cognitive function, resulting in a loss of memory, with neurological and neuropsychiatric manifestations [6, 7]. Cholinergic deficit findings in the postmortem brain was characterized by a significant decrease in acetylcholine amount [8]. Acetylcholinesterase (AChe), a catalytic enzyme, degrades and decrease availability of neurotransmitter acetylcholine useful for neuron innervation and cognitive function $[9,10]$. Drugs that acts on acetylcholinesterase inhibitors play a significant role in the management of AD [11]. However, in spite of availability of these drugs, the patient compliance still not achieved due to burden in cost and untolerable adverse effects such as anorexia, GIT and sleep disturbances $[12,13]$.

Throughout history, plant materials have served as a reservoir of potential new drugs [14]. Herbal medicines provide rational means for the treatment of many diseases that

\footnotetext{
${ }^{*}$ Corresponding author: Ferlien Mae Brieta

†email: fbaula@uic.edu.ph
} 
are incurable in other systems of medicine [6]. The majority of plant-related drugs were discovered had been used traditionally for medicinal properties that were related to the current therapeutic indication [15]. This shows a clear correlation between the ethnomedical uses of the plants and the current use of their derived drugs [16]. Among several herbal medicines available in the market, Galantamine is very popular, an alkaloid isolated from Galanthus nivalis L. (Amaryllidaceae) [15]. Several plant-derived drugs (rivastigmine and galanthamine) that inhibit $\mathrm{AChE}$ can be used to treat early stages of AD, since these compounds increase the endogenous levels of acetylcholine to boost cholinergic neurotransmission [17]. Since most of the acetylcholinesterase inhibitors are known to contain nitrogen, the strong activity of plants belonging to these families may be due to their rich alkaloid content [18]. Many plant-derived alkaloids that act as AChE-I can be considered as models for the development of AD drugs [19]. According to [19], alkaloids isolated from natural sources, such as physostigmine, have been long recognized as acetyl- and butyrylcholinesterase (BChE) inhibitors. In a recent review, 260 chemically defined natural molecules were evaluated for AChE inhibition. Among the compounds tested, alkaloids (139) were classified the most compounds which exhibit anticholinesterase inhibition [20, 21, 22]. Hence, screening of anticholinesterase activity of plants is highly encouraged.

Filipinos are avid follower of eastern traditional medicine due to the abundance of the natural resources in the country. Mindanao is blessed to have rich natural resources, especially indigenous ones that are not yet studied. Indigenous herbal plants have been used as a treatment in vari- ous types of conditions in non-urbanized areas on folkloric practices. Some plants were said to have memory enhancing property and good for the elders. Since these are folkloric claims, scientific evidences must be gathered in order to establish the proper use of these herbal medicines. Hence this study was undertaken to screen the anticholinesterase activity potential of alkaloids from plant extracts of ten selected indigenous plants in Mindanao. The sample that will be used in the study will be limited to the following indigenous plants and their parts: Albahaka/Balanoy (Ocimum basilicum) leaves, Bila bila/ Paragis (Eleusine indica) leaves, Gotu kola (Centella asiatica) leaves, Kangkong (Ipomoea aquatica) leaves, Makahiya (Mimosa pudica) roots, Pakpak Lawin (Drynaria quercifolia) leaves, Pandakaki (Ervatamia pandacaqui) leaves, Pansit-Pansitan (Peperomia pellucida) leaves, Spiral Ginger (Costus barbatus/speciosus) leaves, and Tawa-tawa (Euphorbia hirta) whole plant. Selection of the plants will be based on the presence of alkaloids and on their ethnomedicinal uses as remedies for central nervous system diseases or to enhance memory. The chemical property of the plant extracts was examined using Fourier transform infrared spectroscopy, revealing the functional groups present. The researchers established the toxicity profiles of the plant extracts, if these plants are safe to taken orally following the guidelines of the Organization for Economic Cooperation and Development. Approximate inhibitory concentration of the plant extracts against acetycholinesterase was determined using concentration with logarithmic intervals. The findings were compared to the positive control, Donepezil, a synthetic drug clinical useful for Alzheimer's disease management.
INDEPENDENTVARIABLE

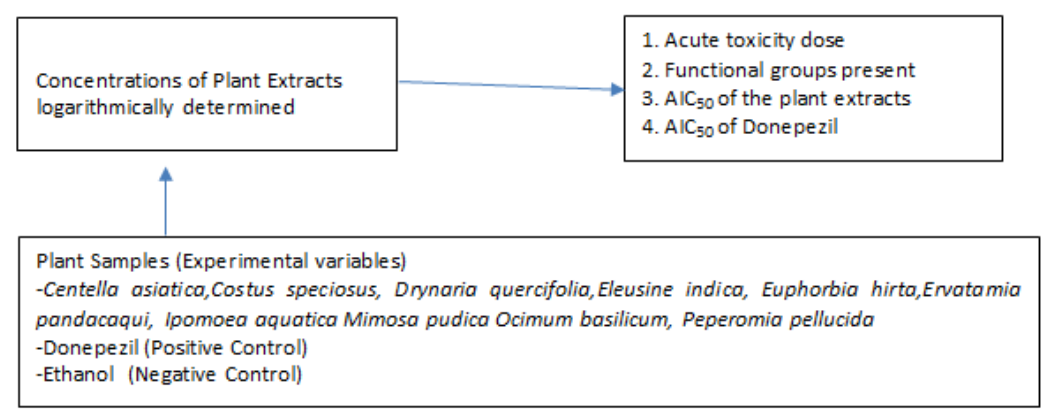

Fig. 1. The conceptual paradigm of the study
Figure 1 depicts the relationship of the independent variable: the concentrations of the ten plant extracts, Donepezil (positive control) and Ethanol (negative control) logarithmically determined, with that of the dependent variable : acute toxicity dose, functional groups present, $\mathrm{AIC}_{50}$ of the plant extracts, and $\mathrm{AIC}_{50}$ of Donepezil.

This research can provide alternative management for simple memory loss, dementia and Alzheimer's disease. The 
researchers aim to discover new natural sources to aid to the development of cheaper new drugs with fewer side effects. Since these 10 selected indigenous plants are exotic, manufacturing firms will have the opportunity to use these plants in developing new drugs that are cheaper and have less side effects. By this, manufacturing firms will have a higher amount of income and at the same time they can help the people in the country in curing their diseases. The information that this study has provided will contribute to the research and development programs of our government agencies. Design for the improvement of health programs, and production of the plants might also arise.With the findings of the study, indigenous plants will be used by community according to scientific evidence-based results. Increase in utilization of these different plants are expected, hence it encourages the local folks to promote propagation and may serve as additional source of income in the community.

\section{METHODS}

\section{A. Research Design}

The researchers will utilize an experimental research design. The researchers will be extracting the dried plant samples by following the method used by [23]. The determination of the $\%$ inhibition activity of acetylcholinesterase of the plant extracts will be based from the modified Ellman method that was used by [24]. The method for the determination ID50 values will be though the method used by [25].

\section{B. Research Locale}

Oral toxicity dose testing was performed at the Animal house of the University of the Immaculate Conception. The FTIR was performed at the Ateneo de Davao University. The Ellman method for anticholinesterase inhibition activity was conducted in the UIC Clinical Laboratory. All other methods were done in the Analytical Chemistry Laboratory in the University the Immaculate Conception. All ten indigenous plants will be collected in Davao City and the provinces close to the mentioned city.

\section{Collection and Authentication of Experimental Se- lected Plants}

The selected indigenous plants were collected within Davao City. The plant will be collected with proper handling and will be placed in a black bag. The plant samples will be preserved for authentication by a botanist in National Museum, Manila.

\section{Culvenor Fitzgerald Field Testing for Alkaloids Method}

Triturate 2-4 grams of the fresh finely cut plant material with sufficient chloroform and clean sand with mortar and pestle. Add 10-mL ammoniacal Chloroform and stir the mixture. Filter into test tube, pressing the material to cover the extract. Add 5.0mL sulfuric acid and shake well. Let stand. Pipette off the clear layer into two small test tubes. Test one portion with Dragendorff's reagent and the other with Mayer's reagent. Use 2-3 drops of each reagent. An orange precipitate with Dragendorff's and white precipitate with Mayer's reagent indicate a positive.

\section{E. Preparation of Selected Indigenous Plants}

The freshly collected leaves of the plants was subjected to air drying for 3 days. Two hundred grams (200 g) of the dried plant material was cut into small pieces and was placed in an Erlenmeyer flask and was macerated in $80 \%$ ethanol for forty-eight hours ( 48 hours). The plant material allowed to be submerged completely in the solvent. After 48 hours, it was filtered through a Buchner funnel and was subjected to Rotary Evaporation (RotaVap) machine at 40-60C. Half of the extract was subjected to lyophilization and the other half was stored in a cold place until used.

\section{F. Determination of Acute Oral Toxicity Test (OECD - 423)}

A. Selection of Animal Species. The OECD guidelines state that for oral acute toxicity test, the preferred species are rodents, normally females were used. Although there is a little difference in sensitivity between sexes, in these cases where differences were observed, females are generally slightly more sensitive than males. Females should not be pregnant. Each animal, at the initiation of its dosing should be between 8-12 weeks old [26]. In this study therefore, female Swiss mice were used.

B. Bioassay. All animals used in the bioassay were treated in accordance with the rules and regulations of the Philippine Welfare Act of 1998. The animals were acclimatized for five days in standard cages maintained at room temperature and $12 \mathrm{hr}$ light/ dark cycles. They were fed with standard diet and allowed access to tap water.

C. Administration of Dose. Animals were fasted prior to dosing. Swiss mice were fasted with food but not water for 3-5 hours. Following the period of fasting, the mice were weighed the test substance was administered. After the substance had been administered, food will be given after 1-2 hours [1]. 
D. Sample Preparation. The final concentration of the extract was determined. Ethanol-free extract was administered orally using a gavage at a dose of $2000 \mathrm{mg} / \mathrm{kg}$ body weight.

\section{G. Approximate Inhibitory Concentration}

1) Reagents and equipment: In the study, ethyl alcohol was used as the solvent for the crude extracts. Electric eel acetylcholinesterase was the test enzyme with acetylthiocholine iodide (the substrate to be used instead of acetylcholine because of its similar qualitative kinetic behavior provides online monitoring of the hydrolysis by the Ellman's method [24], and 5,5-dithio-bis(2-nitrobenzoic acid) (DTNB) will be used as the reagent for the inhibitory assay, and with phosphate buffer, $\mathrm{pH} 8$.

2) Evaluation of ACHe inhibitory activity using ellman's method: Inhibition of ACHe activity was measured using a 96-well microplate reader based on Ellman's method using a UV spectrophotometer. In the 96-well plates, a reaction mixture of $50 \mu \mathrm{l}$ Phosphate Buffer, $30 \mu \mathrm{L}$ enzyme stock solution, $100 \mu \mathrm{l}$ DTNB stock solution and $30 \mu \mathrm{l}$ of the plant extract was added using a micropipette. The mixture was incubated for 5 minutes at $25^{\circ} \mathrm{C}$. It was observed in spectrophotometer 5 times every $13 \mathrm{~s}$ at $412 \mathrm{~nm}$. Thereafter, 30 $\mu \mathrm{l}$ of substrate stock solution was added to the wells and the microplate was read again at the same wavelength 5 times with 13 seconds intervals. Donepezil dissolved in methanol was used as standard drug at concentrations logarithmically determined; a blank of ethanol in $50 \mathrm{mM}$ Phosphate Buffer, $(\mathrm{pH} 8)$ will be used. The $\mathrm{AIC}_{50}$ values was determined by spectrophotometric measurement of the effect of increasing concentrations of test compounds (plant extracts and positive controls) on AChE activity. To calculate the $\mathrm{AIC}_{50}$ values, each sample was assayed at concentrations logarithmically determined. $\mathrm{AIC}_{50}$ values was obtained from dose-effect curves by linear regression [25].

\section{RESULTS AND DISCUSSION}

This section presents and discusses the results from the experiments employed in this study. Data presentation is followed by analysis and interpretation of data which specifically answer the proposed questions in the statement of the problem. From these data, factual and accurate conclusions were formulated. The researchers used the Culvenor-Fitzgerald Test to employ a rapid field test for alkaloid containing plants. Table 1 presents the results of the test.

TABLE 1

\begin{tabular}{ll}
\multicolumn{2}{l}{ CULVENOR-FITZGERALD FIELD TEST } \\
\hline \hline Plant & Alkaloids \\
\hline Centella asiatica & - \\
Costus speciosus & + \\
Drynaria quercifolia & + \\
Eleusine indica & + \\
Euphorbia hirta & + \\
Ervatamia pandacaqui & + \\
Ipomoea aquatica & + \\
Mimosa pudica & + \\
Ocimum basilicum & - \\
Peperomia pellucida & - \\
\hline \hline
\end{tabular}

Development of orange precipitate indicates presence of alkaloids. As presented in Table 1, Bila-Bila, Kangkong, Makahiya, Pandakaki, Pakpak Lawin, Spiral ginger, and Tawa-tawa are positive of alkaloids. On the other hand, Balanoy, Gotu kola and Pansit-pansitan were negative of alkaloids as there was no appearance of a orange precipitate. A pharmacological review by [27], the proponents stated that the primary active constituents of Gotu kola are saponins (also called triterpenoids), which include asiaticosides, in which a trisaccharide moiety is linked to the aglycone asiatic acid, madecassoside and madasiatic acid. Also, according to Globinmed.com, the main components of Pansitpansitan are dillapiol (39.7\%) and trans-caryophyllene. Previous investigations showed it had flavonols and anthraquinones. Alkaloids was very little to none. [28] stated that the major constituents present in Balanoy were methyl eugenol (39.3\%) and methyl chavicol (38.3\%). The presence of essential oils and their composition determines the specific aroma of plants and the flavor of the condiment. To determine the functional groups of the plant extracts, the lyophilized plant extracts were analysed using Fourier Transform Infrared Spectroscopy (FTIR). The findings are presented in Table 2. 
TABLE 2

DETERMINED FUNCTIONAL GROUPS

\begin{tabular}{|c|c|}
\hline Plant & Functional Group \\
\hline \multirow[t]{4}{*}{ Eleusine indica } & $\bullet-\mathrm{OH}$ \\
\hline & - Carbonyl Group \\
\hline & - C-O Group \\
\hline & (Indication of presence of alcohol) \\
\hline Ipomoea aquatica & - - OH group and C-O (Indication of presence of alcohol) \\
\hline \multirow[t]{2}{*}{ Mimosa pudica } & - C-O Group (May be indicative of the presence of ether) \\
\hline & - Amide (N-H Group \& Carbonyl) \\
\hline \multirow[t]{2}{*}{ Drynaria quercifolia } & - Alkene $(\mathrm{C}=\mathrm{C})$ Group \\
\hline & - C-O Group (Indication of presence of alcohol or ether) \\
\hline \multirow[t]{2}{*}{ Ervatamia pandacaqui } & - - OH and C-O Group (Indication of presence of alcohol) \\
\hline & - Alkene $(\mathrm{C}=\mathrm{C})$ Group \\
\hline \multirow[t]{2}{*}{ Costus speciosus } & - Amide (N-H group \& Carbonyl) \\
\hline & - C-O Group (May be indicative of the presence of alcohol or ether) \\
\hline \multirow[t]{2}{*}{ Euphorbia hirta } & -Carbonyl group (aromatic ester OR ketone) \\
\hline & - - OH group \\
\hline
\end{tabular}

Based on the interpreted readings, Makahiya and Spiral Ginger were the only plants present with a nitrogen or an amide group which may be an indication of the presence of alkaloid. Other studies would suggest the presence of alkaloids in Kangkong and Tawa-tawa which may contribute to their anticholinesterase activity. In a study by [29], it was suggested that chlorogenic acid is a chemical found in Ipomoea aquatica that is eyed to exhibit acetylcholinesterase inhibitory activity. The alcohol groups and alkene were both found in chlorogenic acid and the spectra. [10] suggested the occurrence of pyrrolidine amides in Ipomoea aquatica. Ketoesters derivatives of succinimides are known to possess overwhelming anticholinesterase activity [18]. The basic nuclei of succinimide is "pyrrolidine-2,5-dione". The pyrrolidine structure is found in both Ipomoea aquatica and succinimide derivatives. [30] have reported that the total alkaloids isolated from the rhizome of Costus speciosus potentiated the pharmacological actions of acetylcholine both in vitro and in vivo. Alkaloids are characterized by the presence of nitrogen. The results shown in Table 3 reflected the presence of amide group in Spiral Ginger and Makahiya. The employed natural and synthetic drugs in the treatment of AD possess nitrogen atom, aromatic ring and/or carbonyl group in common in their structure. The carbonyl group which may indicate of the presence of an aromatic ester or ketone is present in Euphorbia hirta.

To determine the OECD Category of the of the plant extracts, acute oral toxicity test based on OECD 423 was conducted and observations are presented in Table 3.

TABLE 3

ACUTE SINGLE DOSE TOXICITY TEST

\begin{tabular}{lllllll}
\hline \hline Plant & Concentration of Extract & $N$ & \multicolumn{4}{c}{ Observation Time } \\
\cline { 4 - 6 } & & & 1 hour & 4 hours & 7 days & 14 days \\
\hline Kangkong & 2000 & 3 & Survived & Survived & Survived & Survived \\
Makahiya & 2000 & 3 & Survived & Survived & Survived & Survived \\
Spiral Ginger & 2000 & 3 & Survived & Survived & Survived & Survived \\
Tawa- tawa & 2000 & 3 & Survived & Survived & Survived & Survived \\
\hline \hline
\end{tabular}

Results of the recorded observation showed that none of the test animals died and no Swiss mice has experienced severe pain or enduring signs of severe distress after administration of the fixed doses of the plant material. Furthermore, none of the test animals tested displayed signs of toxicity such as: Changes skin color and eyes, nausea, vomiting, salivation, tremors, convulsions, diarrhea and sleep. According to Agriculture.vic.gov.au, practically all parts of the young plant are edible, although the shoot tips and younger leaves are preferred. Acute oral toxicity test conducted by [23] revealed that the the Kangkong plant extract is safe and is not toxic up to $2000 \mathrm{mg} / \mathrm{kg}$. [31] also used the same 
dose, stated that there was no considerable change in body weight before and after treatment and no sign of toxicity were observed. When the experiment was repeated again with same dose level, $2000 \mathrm{mg} / \mathrm{kg}$ body weight/po of plant extract for 7 more days and observed for fourteen days no change was observed from the experiments. The edibility of the plant may be the cause of the mice survival. In a similar study conducted by [21], Makahiya plant extract was classified as nontoxic material as the mice showed no clinical signs without any mortality included. Another study done by [11] extended the dose up to $5000 \mathrm{mg} / \mathrm{kg}$ and no toxic effects were observed. Hence, there were no lethal effects, which indicated it may have a reasonable safety margin with regards to acute oral toxicity. [29] carried out the acute oral toxicity by using the turner method. The plant extracts were administered orally at four different doses $500,1000,1500,2000 \mathrm{mg} / \mathrm{kg}$ body weight respectively to each group. The results showed both sexes showed up to dose $200 \mathrm{mg} / \mathrm{kg}$ body weight no mortality and no any significant behavioural changes were found during the study. In the study of [24], the researchers used methanolic extract instead of a ethanolic extract. Mimosa pudica methanolic extract did not produce any toxic symptoms or mortality up to the dose level of $2000 \mathrm{mg} / \mathrm{kg}$ body weight in rats, and hence the extract was considered to be safe and nontoxic for further pharmacological screening. Consequently, Kangkong, Makahiya, Spiral Ginger, and Tawa-tawa plant extracts are categorized as a nontoxic material. The classification were based from the guidelines of the Organisation for Economic Co-operation and Development (OECD): Very toxic, $\leq 5 \mathrm{mg} / \mathrm{kg}$ body weight; toxic, $>5 \leq 50 \mathrm{mg} / \mathrm{kg}$; harmful, $>50 \leq 500 \mathrm{mg} / \mathrm{kg}$; and no label, $>500 \leq 2000 \mathrm{mg} / \mathrm{kg}$ (Walum, Environment Health Perspectives 1998). The percentage acetylcholinesterase (AChE) inhibition of the studied plant extracts were done using in vitro analysis by measuring absorbance of the test compounds containing reaction and the absorbance of the reaction control. The $\mathrm{AIC}_{50}$ of the four plant extracts were calculated using linear regression and the $\mathrm{AIC}_{50}$ range was obtained from the computed $\mathrm{AIC}_{50}$. The percent inhibition of the plants at different concentrations and the $\mathrm{AIC}_{50}$ are presented in Table 4.

TABLE 4

DETERMINATION OF AIC ${ }_{50}$ OF IPOMOEA AQUATICA USING LINEAR REGRESSION

\begin{tabular}{llll}
\hline \hline \multicolumn{3}{l}{ Concentration, $\mathrm{mg} / \mathrm{mL}$} & \% Inhibitory Action \\
Actual & \%Inhibition & Computed $\mathrm{AIC}_{50}$ & $\mathrm{AIC}_{50}$ Range \\
\hline 1 & 28.17 & $3.68 \mathrm{mg} / \mathrm{mL}$ & $2.76-4.60 \mathrm{mg} / \mathrm{mL}$ \\
3.98 & 25.46 & & \\
15.84 & 24.91 & & \\
64.06 & 28.36 & & \\
251.10 & 50.59 & & \\
\hline \hline
\end{tabular}

Based from linear regression, the $\mathrm{AIC}_{50}$ of Ipomoea aquatica is $3.68 \mathrm{mg} / \mathrm{mL}$. The computed concentration was obtained based on the plotting of concentration with the inhibitions which yielded a correlation of $R^{2}=0.700$. The approximate inhibitory concentration range of Ipomoea aquatica against acetylcholinesterase using is $2.76 \mathrm{mg} / \mathrm{mL}$ to $4.60 \mathrm{mg} / \mathrm{mL}$. The\% inhibition showed that it is inconsistent in increasing concentrations but has displayed a large increase to $50.59 \%$ at $251.10 \mathrm{mg} / \mathrm{mL}$.

TABLE 5

DETERMINATION OF AIC $_{50}$ OF MIMOSA PUDICA USING LINEAR REGRESSION

\begin{tabular}{llll}
\hline \multicolumn{3}{l}{ Concentration, $\mathrm{mg} / \mathrm{mL}$} & \multicolumn{2}{l}{ \% Inhibitory Action } \\
Actual & \%Inhibition & Computed $\mathrm{AIC}_{50}$ & AIC $_{50}$ Range \\
\hline 1 & 31.81 & $4.18 \mathrm{mg} / \mathrm{mL}$ & $3.13-5.23 \mathrm{mg} / \mathrm{mL}$ \\
3.98 & 33.22 & & \\
15.84 & 32.86 & & \\
64.06 & 34.48 & & \\
251.10 & 34.53 & & \\
\hline \hline
\end{tabular}


Table 4B shows that the $\mathrm{AIC}_{50}$ of Mimosa pudica against acetylcholinesterase using linear regression is $4.18 \mathrm{mg} / \mathrm{mL}$. This leads to the range of $3.13-5.23 \mathrm{mg} / \mathrm{mL}$. When the concentrations was plotted with the inhibitions, it yielded a correlation of $R^{2}=0.848$. [27] evaluated the anticholinesterase activity of Mimosa pudica by measuring the $\mathrm{IC}_{50}$. Results suggest that M. pudica has an $\mathrm{IC}_{50}$ of $3.04 \mathrm{mg} / \mathrm{mL}$. The obtained $\mathrm{IC}_{50}$ is very close to the $\mathrm{AIC}_{50}$ range that the researchers had obtained. Also, it was concluded in the study that M. pudica roots showed higher values of inhibition than its leaves.

TABLE 6

\begin{tabular}{|c|c|c|c|}
\hline \multicolumn{2}{|c|}{ Concentration, $\mathrm{mg} / \mathrm{mL}$} & \multicolumn{2}{|c|}{ \% Inhibitory Action } \\
\hline Actual & \%Inhibition & Computed $\mathrm{AIC}_{50}$ & $\mathrm{AIC}_{50}$ Range \\
\hline 1 & 30.65 & $4.18 \mathrm{mg} / \mathrm{mL}$ & $3.13-5.23 \mathrm{mg} / \mathrm{mL}$ \\
\hline 3.98 & 30.83 & & \\
\hline 15.84 & 32.16 & & \\
\hline 64.06 & 35.96 & & \\
\hline 251.10 & 33.29 & & \\
\hline
\end{tabular}

Results show that the highest inhibition obtained was $35.96 \%$ at $64.06 \mathrm{mg} / \mathrm{mL}$. Using the linear regression, the $\mathrm{AIC}_{50}$ of Costus speciosus is $4.18 \mathrm{mg} / \mathrm{mL}$. The $\mathrm{AIC}_{50}$ of $C$. speciosus and M.pudica is observed to be similar. The ap- proximate inhibitory concentration range of Costus speciosus against acetylcholinesterase is $3.13 \mathrm{mg} / \mathrm{ml}$ to 5.23 $\mathrm{mg} / \mathrm{ml}$.

TABLE 7

DETERMINATION OF AIC ${ }_{50}$ OF EUPHORBIA HIRTA USING LINEAR REGRESSION

\begin{tabular}{llll}
\hline \multicolumn{3}{l}{ Concentration, $\mathrm{mg} / \mathrm{mL}$} & \% Inhibitory Action \\
Actual & \%Inhibition & Computed $\mathrm{AIC}_{50}$ & $\mathrm{AIC}_{50}$ Range \\
\hline 1 & 32.69 & $3.74 \mathrm{mg} / \mathrm{mL}$ & $2.81-4.68 \mathrm{mg} / \mathrm{mL}$ \\
3.98 & 29.83 & & \\
15.84 & 20.52 & & \\
64.06 & 55.65 & & \\
251.10 & 35.92 & & \\
\hline \hline
\end{tabular}

A series of six concentrations of Euphorbia hirta extract ranging from 1to $251.10 \mathrm{mg} / \mathrm{L}$ were used to identify the $\mathrm{AIC}_{50}$. Computations were done using linear regression which revealed a concentration of $3.74 \mathrm{mg} / \mathrm{mL}$. The approximate inhibitory concentration range of Euphorbia hirta against acetylcholinesterase is $2.81 \mathrm{mg} / \mathrm{ml}$ to $4.68 \mathrm{mg} / \mathrm{ml}$. The $R^{2}$ is .156. No existing studies have been conducted to evaluate the anticholinesterase activity of $E$. hirta by computing the $\mathrm{IC}_{50}$. However, [27] stated that the anxiolytic effects of E. hirta in rats subjected to CIS was due to suppression of CIS-induced AChE activity in the frontal cortex, hippocampus, and septum brain regions. The said suppression of AChE activity could be attributed to the anticholinesterase inhibitory activity of $E$. hirta.

TABLE 8

\begin{tabular}{|c|c|c|c|}
\hline \multicolumn{2}{|c|}{ Concentration, $\mathrm{mg} / \mathrm{mL}$} & \multicolumn{2}{|c|}{$\%$ Inhibitory Action } \\
\hline Actual & \%Inhibition & Computed $\mathrm{AIC}_{50}$ & $\mathrm{AIC}_{50}$ Range \\
\hline 1 & 22.79 & $4.15 \mathrm{mg} / \mathrm{mL}$ & $3.11-5.19 \mathrm{mg} / \mathrm{mL}$ \\
\hline 3.98 & 26.69 & & \\
\hline 15.84 & 28.14 & & \\
\hline 64.06 & 30.99 & & \\
\hline 251.10 & 33.27 & & \\
\hline
\end{tabular}


It can be inferred from the $\%$ inhibition at increasing concentrations that both have a direct relationship. The approximate inhibitory concentration of Donezepil, the positive control, against acetylcholinesterase using linear regression is $4.15 \mathrm{mg} / \mathrm{mL}$ and the approximate inhibitory range is $3.11-5.19 \mathrm{mg} / \mathrm{mL}$. The computed concentration was obtained based on the plotting of concentration with the inhibitions which yielded a correlation of $R^{2}=0.986$. To examine if there was a significant difference in the $\mathrm{AIC}_{50}$ of Costus speciosus, Euphorbia hirta, Ipomoea aquatica and Mimosa pudica compared to the positive control (Donepezil), $T$-test was conducted.

TABLE 9

T-TEST RESULT

\begin{tabular}{|c|c|c|c|c|c|c|}
\hline \multicolumn{5}{|c|}{ Approximate Inhibitory Concentration 50\% } & \multirow{2}{*}{$\begin{array}{l}\text { Sig value }(\alpha=.05,2 \text {-tailed }) \\
0.287\end{array}$} & \multirow{2}{*}{$\begin{array}{l}\text { Inference } \\
\text { Accept null hypothesis }\end{array}$} \\
\hline 3.68 & 4.18 & 4.18 & 3.74 & 4.15 & & \\
\hline
\end{tabular}

Table 9 shows that the significant value 0.287 is greater than $\alpha=.05$ (2-tailed). Hence, the researchers failed to reject the null hypotheses that there is no significant $\mathrm{AIC}_{50}$ difference: between Ipomoea aquatica and the positive control (Donepezil); between Mimosa pudica root inulin and the positive control (Donepezil); between Euphorbia hirta and the positive control (Donepezil); and between Costus speciosus and the positive control (Donepezil). It means that the $\mathrm{AIC}_{50}$ difference between the four plant extracts and the positive control (Donepezil) is not statistically significant. Overall, findings suggest that the $\mathrm{AIC}_{50}$ of the four plant extracts and the positive control (Donepezil) is statistically equal. Inhibition of AChE, the key enzyme in the breakdown of acetylcholine, is considered one of the treatment strategies against several neurological disorders including AD. In this study, the approximate inhibitory concentration $\left(\mathrm{AIC}_{50}\right.$ ) of Costus speciosus, Euphorbia hirta, Ipomoea aquatica and Mimosa pudica were acquired. It can be observed that the\% inhibition of the extracts are higher than the positive control (Donepezil). Since most of the acetylcholinesterase inhibitors are known to contain nitrogen, the activity of the plants may be due to their rich alkaloid content [18]. The plant extracts tested having the inhibitory concentration ranging between $15-50 \%$ are said to have moderate activity against AChE [15]. However, the $\mathrm{AIC}_{50}$ difference between the four plant extracts and the positive control (Donepezil) is not statistically significant and is statistically equal.

\section{SUMMARY}

This study was done with the intent to screen the acetylcholinesterase activity of alkaloids from plant extracts of ten indigenous plants in Mindanao. The plant materials were obtained from different areas in Mindanao. The rapid determination of alkaloid in the plant samples in the field was done using Culvenor-Fitzgerald Test. Costus speciosus, Drynaria quercifolia, Eleusine indica, Euphorbia hirta, Er- vatamia pandacaqui, Ipomoea aquatica and Mimosa pudica were found positive of alkaloids. Determination of the functional groups which may attribute to the anticholinesterase activity was done using the Fourier Transform Infrared Spectroscopy (FTIR). The presence of nitrogen, carbonyl group, hydroxyl groups and aromatic rings were found in Costus speciosus, Euphorbia hirta, Ipomoea aquatica and Mimosa pudica. The results of acute oral toxicity test show that at $2000 \mathrm{mg} / \mathrm{kg}$, Costus speciosus, Euphorbia hirta, Ipomoea aquatica and Mimosa pudica extracts are classified as Category 5: practically non-toxic based on the Globally Harmonised System [1]. This data provide the idea of the use of the approximate inhibitory concentration range starting $1 \mathrm{mg} / \mathrm{mL}$. Another purpose of this study is to acquire the approximate inhibitory concentration $\left(\mathrm{AIC}_{50}\right)$ of the extracts using the Ellman method to determine the\% inhibition at concentrations logarithmically determined and linear regression was used to calculate the $\mathrm{AIC}_{50}$. The $\mathrm{AIC}_{50}$ of Costus speciosus, Euphorbia hirta, Ipomoea aquatica and Mimosa pudica extracts are $4.18 \mathrm{mg} / \mathrm{mL}, 3.74 \mathrm{mg} / \mathrm{mL}, 3.68 \mathrm{mg} / \mathrm{mL}$, $4.18 \mathrm{mg} / \mathrm{mL}$, respectively and their corresponding $\mathrm{AIC}_{50}$ range are $3.13-5.23 \mathrm{mg} / \mathrm{mL}, 2.81-4.68 \mathrm{mg} / \mathrm{mL}, 2.76-4.60$ $\mathrm{mg} / \mathrm{mL}$ and 3.13-5.23 mg/mL. Furthermore, the $\mathrm{AIC}_{50}$ of the plant extracts were compared statistically with the positive control (Donepezil), to know if there is a significant difference. Results show that the significant value 0.287 is greater than $\alpha=.05$ (2-tailed). Hence, the researchers failed to reject the null hypotheses that there is no significant AIC50 difference between of Costus speciosus, Euphorbia hirta, Ipomoea aquatica and Mimosa pudica extracts and the positive control, Donepezil.

\section{CONCLUSION}

The study has provided answers to the questions listed under the statement of the problem. The answers are listed below: 1 . Seven out ten plants gave positive results from alkaloid field testing. 
2. IR spectra of the plants gave common functional groups: Amides, carbonyls and hydroxyl groups.

3. The results of acute oral toxicity test show that at $2000 \mathrm{mg} / \mathrm{kg}$, Costus speciosus, Euphorbia hirta, Ipomoea aquatica and Mimosa pudica extracts is classified as Category 5: practically non-toxic based on the Globally Harmonised System [1].

A. The $\mathrm{AIC}_{50}$ of Costus speciosus is $4.18 \mathrm{mg} / \mathrm{mL}$ and its $\mathrm{AIC}_{50}$ range is $3.13-5.23 \mathrm{mg} / \mathrm{mL}$. B. The $\mathrm{AIC}_{50}$ of Euphorbia hirta is $3.74 \mathrm{mg} / \mathrm{mL}$ and its $\mathrm{AIC}_{50}$ range is $2.81-4.68 \mathrm{mg} / \mathrm{mL}$. C. The $\mathrm{AIC}_{50}$ of Ipomoea aquatica is $3.68 \mathrm{mg} / \mathrm{mL}$ and its $\mathrm{AIC}_{50}$ range is $2.76-4.60 \mathrm{mg} / \mathrm{mL}$. D. The $\mathrm{AIC}_{50}$ of Mimosa pudica is $4.18 \mathrm{mg} / \mathrm{mL}$ and its $\mathrm{AIC}_{50}$ range is $3.13-5.23 \mathrm{mg} / \mathrm{mL}$. 4. There is no significant difference between the $\mathrm{AIC}_{50}$ of Costus speciosus, Euphorbia hirta, Ipomoea aquatica and Mi- mosa pudica and the positive control (Donepezil) against acetylcholinesterase.

\section{RECOMMENDATIONS}

The researchers apprehend the need to propose the following:

1. To get the half maximal inhibitory concentration $\left(\mathrm{IC}_{50}\right)$ of the plant extracts using the $\mathrm{AIC}_{50}$.

2. To perform in vivo tests using the plant extract that has a promising anticholinesterase activity from the $\mathrm{IC}_{50}$.

3. To test other plants that have the potential acetylcholinesterase activity.

4. To test for the anticholinesterase activity of different secondary metabolites from plants with potential acetylcholinesterase activity.

\section{REFERENCES}

[1] Organisation for Economic Co-operation and Development, "The well-being of nations," 2001. [Online]. Available: https://urlzs.com/ungcj

[2] B. Frank and S. Gupta, "A review of antioxidants and alzheimer's disease," Annals of Clinical Psychiatry, vol. 17, no. 4, pp. 269-286, 2005. doi: https://doi.org/10.1080/10401230500296428

[3] D. J. Selkoe, "Alzheimer's disease: Genes, proteins, and therapy," Physiological Reviews, vol. 81, no. 2, pp. 741-766, 2001. doi: https://doi.org/10.1152/physrev.2001.81.2.741

[4] B.-W. E. S. R. Lipton, "Sa. molecular pathways to neurodegeneration," Nat Medical, vol. 10, no. 6, pp. 34-56, 2004.

[5] A. S. Susuman, "Mental health issues and policy in Sub Saharan Africa: A view from Cape Town to Cairo," International Journal of Health and Medical Sciences, vol. 3, no. 3, pp. 59-66, 2017.

[6] K. Hostettmann, A. Borloz, A. Urbain, and A. Marston, "Natural product inhibitors of acetylcholinesterase," Current Organic Chemistry, vol. 10, no. 8, pp. 825-847, 2006. doi: https://doi.org/10.2174/138527206776894410

[7] E. Manu and M. J. Ntsaba, "Perceptions of marijuana use: Chronicles of marijuana smokers from two marijuanagrowing communities in South Africa," Journal of Advances in Health and Medical Sciences, vol. 2, no. 3, pp. 82-91, 2016. doi: https://doi.org/10.20474/jahms2.3.1

[8] D. L. Bachman, P. A. Wolf, R. Linn, J. E. Knoefel, J. CobbS, A. Belanger, and L. R. White, "Prevalence of dementia and probable senile dementia of the alzheimer type in the framingham study," Neurology, vol. 42, no. 1, pp. 115-119, 1992. doi: https://doi.org/10.1212/wnl.42.1.115

[9] L. E. Hebert, P. A. Scherr, L. A. Beckett, M. S. Albert, D. M. Pilgrim, M. J. Chown, and D. A. Evans, "Age-specific incidence of Alzheimer's disease in a community population," The Journal of the American Medical Association, vol. 273, no. 17, pp. 1354-1359, 1995. doi: https://doi.org/10.1001/jama.273.17.1354

[10] S. Melani, R. N. Emytri, A. Turnip, and B. Q. Aini, “The forming of standard operating procedures for non-prescription drugs service in Apotek Keluarga Bekasi," International Journal of Health and Medical Sciences, vol. 1, no. 3, pp. 57-64, 2015. doi: https://doi.org/10.20469/ijhms.30003-3

[11] J. S. Birks, "Cholinesterase inhibitors for Alzheimer's disease," Cochrane Database of Systematic Reviews, vol. 32, no. 11, pp. 508-511, 2006. doi: https://doi.org/10.1055/s-2006-956993

[12] J. M. Ellis, "Cholinesterase inhibitors in the treatment of dementia," Journal of the American Osteopathic Association, vol. 105, no. 3, pp. 145-150, 2005.

[13] L. S. Schneider, "Treatment of alzheimer's disease with cholinesterase inhibitors," Clinics in Geriatric Medicine, vol. 17, no. 2, pp. 337-358, 2001. doi: https://doi.org/10.1016/s0749-0690(05)70072-0

[14] S. A. Muljo, K. M. Ansel, C. Kanellopoulou, D. M. Livingston, A. Rao, and K. Rajewsky, “Aberrant t cell differentiation in the absence of dicer," Journal of Experimental Medicine, vol. 202, no. 2, pp. 261-269, 2005. doi: https://doi.org/10. 
1084/jem.20050678

[15] W. P. Jones, Y. W. Chin, and A. D. Kinghorn, "The role of pharmacognosy in modern medicine and pharmacy," Current Drug Targets, vol. 7, no. 3, pp. 247-264, 2006. doi: https://doi.org/10.2174/138945006776054915

[16] G. Samuelsson, Drugs of Natural Origin: A Textbook of Pharmacognosy. Stockholm, Sweden: Swedish Pharmaceutical Press, 2004.

[17] L. J. Scott and K. L. Goa, "Galantamine," Drugs, vol. 60, no. 5, pp. 1095-1122, 2000. doi: https://doi.org/10.2165/ 00003495-200060050-00008

[18] I. Orhan, B. Sener, M. I. Choudhary, and A. Khalid, “Acetylcholinesterase and butyrylcholinesterase inhibitory activity of some Turkish medicinal plants," Journal of Ethnopharmacology, vol. 91, no. 1, pp. 57-60, 2004. doi: https://doi.org/ 10.1016/j.jep.2003.11.016

[19] E. L. Konrath, C. D. S. Passos, L. C. Klein Junior, and A. T. Henriques, “Alkaloids as a source of potential anticholinesterase inhibitors for the treatment of Alzheimer's disease," Journal of Pharmacy and Pharmacology, vol. 65, no. 12, pp. 1701-1725, 2013. doi: https://doi.org/10.1111/jphp.12090

[20] M. J. R. Howes, P. J. Houghton, and P. Jenner, "In-vitro screening for anticholinesterase activity of plants used traditionally for memory improvement," Journal of Pharmacy and Pharmacology, vol. 51, no. 4, pp. 238-245, 1999. doi: https: //doi.org/10.20431/2454-7999.0302005

[21] J. M. Barbosa-Filho, M. R. Piuvezam, M. D. Moura, M. S. Silva, K. V. B. Lima, E. V. L. Da-Cunha, and O. S. Takemura, “Antiinflammatory activity of alkaloids: A twenty-century review," Revista Brasileira de Farmacognosia, vol. 16, no. 1, pp. 109-139, 2006. doi: https://doi.org/10.1590/s0102-695x2006000100020

[22] G. F. Longstreth, W. G. Thompson, W. D. Chey, L. A. Houghton, F. Mearin, and R. C. Spiller, "Functional bowel disorders," Gastroenterology, vol. 130, no. 5, pp. 1480-1491, 2006. doi: https://doi.org/10.1053/j.gastro.2005.11.061

[23] P. Tiwari, B. Kumar, M. Kaur, G. Kaur, and H. Kaur, "Phytochemical screening and extraction: A review," Internationale Pharmaceutica Sciencia, vol. 1, no. 1, pp. 98-106, 2011.

[24] A. Komersova, K. Komers, and A. Cegan, "New findings about Ellman's method to determine cholinesterase activity," Zeitschrift fur Naturforschung C, vol. 62, no. 1, pp. 150-154, 2007. doi: https://doi.org/10.1515/znc-2007-1-225

[25] M. S. Ali Shtayeh and S. I. Abu Ghdeib, "Antifungal activity of plant extracts against dermatophytes," Mycoses, vol. 42, no. 11, pp. 665-672, 1999. doi: https://doi.org/10.1046/j.1439-0507.1999.00499.x

[26] Organisation for Economic Co-operation and Development, "Education at a glance 2001," 2011. [Online]. Available: https://urlzs.com/Ddu6m

[27] K. J. Gohil, J. A. Patel, and A. K. Gajjar, "Pharmacological review on centella asiatica: A potential herbal cure-all," Indian Journal of Pharmaceutical Sciences, vol. 72, no. 5, pp. 546-550, 2010. doi: https://doi.org/10.4103/0250-474x.78519

[28] B. Frank and S. Gupta, "A review of antioxidants and Alzheimer's disease," Annals of Clinical Psychiatry, vol. 17, no. 4, pp. 269-286, 2005. doi: https://doi.org/10.1080/10401230500296428

[29] J. Morrissey, B. Meyrick, D. Sivaraman, R. E. Horne, and M. Berry, "Cost-benefit assessment of energy efficiency investments: Accounting for future resources, savings and risks in the Australian residential sector," Energy Policy, vol. 54, no. 5, pp. 148-159, 2013. doi: https://doi.org/10.1016/j.enpol.2012.11.005

[30] K. R. Bhattacharya, C. M. Sowbhagya, and Y. I. Swamy, "Interrelationship between certain physicochemical properties of rice," Journal of Food Science, vol. 37, no. 5, pp. 733-735, 1972. doi: https://doi.org/10.1111/j.1365-2621.1972. tb02738.x

[31] S. Dhanasekaran, T. M. Doherty, and J. Kenneth, "Comparison of different standards for real-time PCR-based absolute quantification," Journal of Immunological Methods, vol. 354, no. 1, pp. 34-39, 2010. doi: https://doi.org/10.1016/j.jim. 2010.01.004 